\title{
Evaluation of Soil and Groundwater Quality at the New Georgia Open Dumpsite in Caldwell, Liberia
}

\author{
Cecelia F Fallah ${ }^{1}$, Lenn G Gomah ${ }^{1,3 *}$, , Rafael S Ngumbu ${ }^{2,3}$, Joseph F Charles ${ }^{1,3}$, and Yekeh \\ Howard ${ }^{3}$ \\ ${ }^{1}$ Department of Research, Honors College of Research and Gender Studies, University of Liberia, Monrovia, Liberia \\ ${ }^{2}$ Department of Chemistry, T.J.R. Faulkner College of Science, University of Liberia, Monrovia, Liberia \\ ${ }^{3}$ Department of Compliance and Enforcement, Environmental Protection Agency, Monrovia, Liberia
}

\begin{abstract}
Leaching emanating from municipal solid waste dumpsite is one of the major causes of soil and groundwater contamination. This study was conducted to determine the extent to which the open dumpsite in New Georgia, Liberia has impacted soil and groundwater quality in the vicinity and recommend strategy to reduce those impacts where quality issues are critical. For this purpose, soil and groundwater samples were collected during the rainy and dry seasons at various locations in the study area and analyzed for a collection of physicochemical parameters ( $\mathrm{pH}$, Turbidity, Electrical Conductivity, Total Dissolved Solids, Nitrate, Phosphate, Copper, Zinc, Cadmium and Lead) using Colorimetric and Atomic Absorption Spectroscopic techniques and microbial parameters (Faecal Coliform and Total Coliform) using Membrane Filtration techniques. Results from the groundwater samples showed values of many parameters within limit of World Health Organization (WHO). However, the values for microbial parameters, as well as turbidity, phosphate, cadmium and lead exceeded the regulatory limit or were just on the benchmark. With the exception of phosphate and copper, all the other parameters showed decreasing trends in values from soil to water and from rainy season to dry season. A decrease in values was also observed as the samples moved further way from the dumpsite. Cumulative water quality index value showed that the sampled groundwater sources in the study area are unsuitable for drinking. Hence, residence should be cautioned about drinking water from all of the tested sources, and measures should be put in place to provide alternative water supplies. Furthermore, the garbage at the dumpsite should be removed and the site properly remediated to avoid impending environmental health adversities.
\end{abstract}

\section{Keywords}

Liberia, Soil, Groundwater, Physicochemical, Microbial, Dumpsite

\section{Introduction}

The large-scale generation of municipal solid waste and its inadequate disposal and management are global issues that hinder the progress towards environmental sustainability and pose several challenges to modern societies [1]. Studies have shown that more than $50 \%$ of less developing countries' population lack consistent access to waste collection services $[2,3]$. Hence, the dumping of untreated waste in open dumpsite has become a major practice for municipal solid wastes disposal [4].

Open dumpsite has been considered as one of the major sources of soil contamination and subsequently groundwater pollution. According to research [5-7], the emanation of leachate containing organic and inorganic matters and heavy metals from an open dumpsite can infiltrate subsurface and subsequently pollutes groundwater. The level of a consequent pollution depends on the concentration and toxicity of the contaminants, depth of watertable, and direction of groundwater flow.

With $98 \%$ of available freshwater, groundwater is a major source of drinking water around the world [8]. It is an important renewable resource that has a self-cleansing ability. However, in recent years, the risk of groundwater

*Corresponding author: Lenn G Gomah, Department of Research, Honors College of Research and Gender Studies, University of Liberia, Monrovia, Liberia, Tel: +231 776946161; $+231880878363$

Accepted: July 22, 2021

Published online: July 24, 2021

Citation: Fallah CF, Gomah LG, Ngumbu RS, et al. (2021) Evaluation of Soil and Groundwater Quality at the New Georgia Open Dumpsite in Caldwell, Liberia. J Soil Water Sci 5(2):197-204 
pollution in developing and underdeveloped countries particularly due to poor waste management has become one of the most important environmental and public health concerns [8]. Waste causes the most pollution to aquifers and their content in groundwater if it is not properly managed and disposed. Several studies conducted around the world have documented the effect of waste deposit on soil and groundwater qualities [9-11].

In Liberia, open dumping of municipal solid waste has become a major practice in many urban cities. Due to lack of legislation and proper waste management plans, open dumpsites are seen near almost every marketplace, commercial centers and along the roads of congested environment [12].

The New Georgia open dumpsite is the major dumpsite serving the burgh of Caldwell. Wastes from various parts of the city are being collected and dumped into the dump site. The major market in Caldwell and residential areas are in proximity to the dumpsites. The main source of potable water in Caldwell is groundwater, commonly supplied from shallow hand-dug wells and/or deeper wells. Residence in the community depends on ground water supply for drinking and domestic purposes. Since the pollution of soil and groundwater by open dumpsite can lead to adverse effect on the environment and public health [13], assessing groundwater quality in the Caldwell is essential. Moreover, there have been several studies conducted to assess the effect of open dumpsite on soil and groundwater qualities, but no study has been conducted in Caldwell, Liberia. This study is undertaken for supporting soil and groundwater pollution remediating strategies and approving groundwater resources management in Caldwell.

\section{Materials and Methods}

\section{Description of study area}

The study area is a part of the Monrovia Quandrangle that lies within the Guinean shield of the West African craton rock formation. It is mostly made up of garnite, schist and gneiss and falls within the Archean Age Province. In Liberia this shield has been intensely folded and faulted and is interspersed with iron-bearing formations known as itabirites. Laterite and saprolite covers most of the roads in the study area. Generally, the study area has a uniform tropical climate comprising of two seasons, the rainy and dry season with a transitional period (December to February) that brings in the Hermitian wind from the Sahara Desert which cause a fluctuation in the temperature to drop to a minimum of 50 degrees Fahrenheit. The annual temperature is between 70 to 80 degrees Fahrenheit having an average rainfall of 75 inches [14].

The dumpsite in this area is the most active dumpsite due to it being in proximity to the principle market of New Georgia. The site consists of composite waste and represents a typical risk of pollution. The waste is usually open burned by marketers because it is not collected by the city ordinance. As indicated by contours on the map below, water flows from the dumpsite in all directions to various steeps or down gradients. Study of soil quality in the study area revealed predominantly sand and silt type of soil. Sandy soils are known to have high permeability, which results in high permeation rates and good drainage [15]. A preliminary survey of about 100 households in the study community showed that about $60 \%$ of the residents use groundwater from boreholes for drinking and domestic purposes (Figure 1).

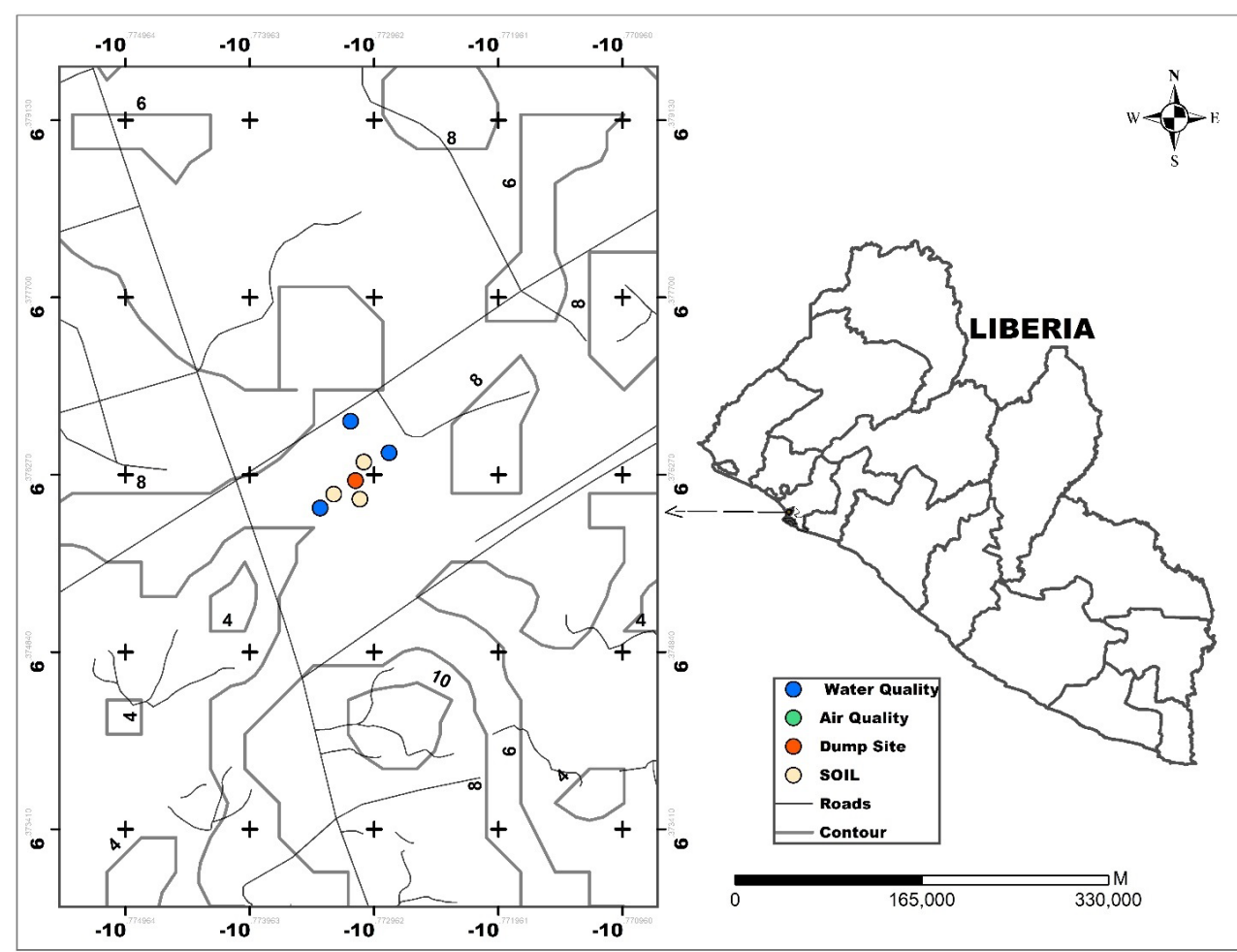

Figure 1: Location of the study area. 


\section{Sampling}

A total of 36 samples of soil and water were collected in this study. The samples consisted of 3 soil samples and 3 groundwater samples collected in triplicate each during the rainy season and the dry season. The soil samples were acquired at the depth of $30 \mathrm{~cm}$ each using soil sampling augers and placed in a labeled airtight polythene bag and sent to the laboratory for analysis. Sterile disposable gloves were worn interchangeably to keep hands safe and avoid inter-contamination of the samples. Water samples were collected from shadowed hand dug wells in $500 \mathrm{ml}$ sampling bottles. The bottles were previously cleaned by soaking in $10 \%$ nitric acid, rinsed with distilled water and rinsed again thrice at the sampling site. Each sampling container was properly corked after filling, kept in a cool box with ice-chest and then transferred to the laboratory for safe custody under refrigerated conditions to avoid sample deterioration. The samples were collected at varying distances from the center of the dumpsite into the residential area at different locations. Table 1 shows the various distances away from the dumpsite at which each sample was collected.

\section{Sample analysis}

A collection of physicochemical parameters $(\mathrm{pH}$, Turbidity, electrical conductivity, total dissolved solids, nitrate, phosphate, copper, zinc, cadmium and lead) and microbial parameters (Faecal coliform and Total Coliform) were analyzed in this study. Various analytical techniques were used to analyze the samples. The concentrations of phosphate and nitrate were determined by Colorimetric techniques (Cadmium Reduction Methods and Molybdovanadate Method respectively) using a DR 890 Hach Colorimeter. The concentrations of copper (Cu), zinc $(\mathrm{Zn})$, cadmium (Cd) and lead $(\mathrm{Pb})$ in the groundwater and soil samples were determined by Flame Atomic Absorption Spectroscopic (AAS) techniques using a Perkins Elmer PinAAcle 500 AAS after digestion with aqua regia (3:1 Nitric-Hydrochloric acids) and a mixture of 2:1:1 Nitric-Sulfuric-Hydrochloric acid respectively. Total coliforms and faecal coliforms in the water samples were determined by Membrane Filtration technique using a Wagtech Microbiological Water Quality Testing Kit. Fast changing parameter such as $\mathrm{pH}$, Turbidity, Electrical Conductivity (EC) and Total Dissolved Solids (TDS) were determined insitu using a Multi Parameter Wagtech Water Quality Monitoring Kit. Appropriate standards with varying concentrations were used to calibrate the equipment prior to analysis.

\section{Quality assurance}

Analyses of all samples were performed in triplicate and the results were presented as cumulative mean. All glass wares were washed properly, rinsed with distilled water and kept in nitric acid solution for about 24 hours and rinsed with distilled water prior to use. Distilled water was used for all dilutions of samples.

\section{Quality assessment}

The quality of the ground water was assessed by comparing the levels of each parameter obtained with its World
Health Organization (WHO) recommended standard values. Additionally, Water Quality Index (WQI) was calculated and values were compared with the index rating classification proposed by Tiwari and Mishra [16]. WQI is calculated using equation 1.

$$
W Q I=\sum_{i}^{n}=1 \frac{S I}{R w}
$$

Equ 1.

Where "SI" is the sub quality index for the parameters and " $\mathrm{Rw}$ " is the relative weight for the parameters. SI is the product of the quality ratings $(\mathrm{Rq})$ and relative weightings (Rw) of the parameters. Rq and Rw were calculated according to equation 2 and 3 respectively.

$$
R q=\left[\frac{C p-7}{S p-7}\right] 100 \text { for } \mathrm{pH} \text { and } R q=\left(\frac{C p}{S p}\right) 100 \text { for }
$$

other parameters Equ 2.

$$
R w=\frac{1}{S p} \text { Equ } 3 .
$$

Where " $\mathrm{Cp}$ " is the mean concentration of the physicochemical parameter in all the water samples, "Sp" is the recommended WHO standard value of the parameter, and 7 is the recommended value of $\mathrm{pH}$. The water quality indices were categorized into five categories according to Tiwari and Mishra as reported by Kachroud, et al. [16]: Excellent (0 to $25)$, Very good (26 to 50), Good (61 to 75 ), Poor (76 to 100) and Unsuitable for drinking if WQI (> 100).

\section{Results and Discussion}

The study was conducted to determine the extent to which the open dumpsite in New Georgia, Liberia, has impacted soil and groundwater quality in the vicinity and recommend strategy to reduce those impacts where quality issues are critical. For this purpose, soil and groundwater samples were collected during the rainy and dry seasons at various locations in the study area and analyzed for a collection of physicochemical and microbial parameters Results from the study are compared against the WHO standard and presented in tables and figures in this section.

Generally, all the samples recorded $\mathrm{pH}$ values (as shown in Table 2 and Table 3 ) in the acidic range for both sampling periods and showed a decreasing trend from dry season to rainy season in the soil samples. This implied that the alkalinity and acidity of soil quality in the study area can be attributed to the activities of the dumpsite. The $\mathrm{pH}$ of surrounding soil might have increased as a result of mixture of volcanic gases or gaseous emanations from the dumpsite. Moreover, rain water, which also increases the acidity of water, may carry leachate emanating from the dumpsite [17]. The results found in the groundwater samples were in the permissive limit (6.0 to 9.0) indicated for drinking water by the World Health Organization and were similar to those reported by other authors [18-20] (Figure 2).

The absorption of incident light by microorganisms and the presence of dissolved and suspended particles produce turbid waters. The World Health Organization recommends 
Citation: Fallah CF, Gomah LG, Ngumbu RS, et al. (2021) Evaluation of Soil and Groundwater Quality at the New Georgia Open Dumpsite in Caldwell, Liberia. J Soil Water Sci 5(2):197-204

Table 1: Distance (in meters) of the samples relatives to the dumpsite.

\begin{tabular}{|c|c|c|c|c|c|}
\hline No. & Sample (Soil) & Distance $(\mathbf{m})$ & No. & Sample (Water) & Distance (m) \\
\hline 1. & S Sample 1 & 110 & 1. & W Sample 1 & 216 \\
\hline 2. & S Sample 2 & 218 & 2. & W Sample 2 & 415 \\
\hline 3. & S Sample 3 & 500 & 3. & W Sample 3 & 800 \\
\hline
\end{tabular}

Table 2: Results of Physicochemical parameters in Soil for each sampling period.

\begin{tabular}{|c|c|c|c|c|c|c|c|c|}
\hline \multirow[b]{2}{*}{ Sample Code } & \multicolumn{4}{|c|}{ Dry Season } & \multicolumn{4}{|c|}{ Rainy Season } \\
\hline & $\mathbf{n}$ & $\mathrm{pH}$ & $\mathrm{NO}_{3}(\mathrm{mg} / \mathrm{kg})$ & $\mathrm{PO}_{4}(\mathrm{mg} / \mathrm{kg})$ & $\mathrm{n}$ & $\mathrm{pH}$ & $\mathrm{NO}_{3}(\mathrm{mg} / \mathrm{kg})$ & $\begin{array}{c}\mathrm{PO}_{4} \\
(\mathrm{mg} / \mathrm{kg})\end{array}$ \\
\hline S Sample 1 & 3 & $6.74 \pm 0.15$ & $3.13 \pm 0.71$ & $1.13 \pm 0.15$ & 3 & $6.33 \pm 0.15$ & $3.90 \pm 0.56$ & $1.05 \pm 0.99$ \\
\hline S Sample 2 & 3 & $6.64 \pm 0.21$ & $3.04 \pm 0.07$ & $1.12 \pm 0.20$ & 3 & $6.41 \pm 0.35$ & $3.04 \pm 0.07$ & $1.12 \pm 0.20$ \\
\hline S Sample 3 & 3 & $6.53 \pm 0.16$ & $3.03 \pm 0.05$ & $0.89 \pm 0.09$ & 3 & $6.38 \pm 0.32$ & $3.09 \pm 0.34$ & $0.98 \pm 0.07$ \\
\hline
\end{tabular}

Table 3: Results of Physicochemical parameters in groundwater for each sampling period.

\begin{tabular}{|c|c|c|c|c|c|c|c|}
\hline \multicolumn{7}{|c|}{ Dry Season } \\
\hline Sample Code & $\mathbf{n}$ & $\mathbf{p H}$ & Turbidity (NTU) & $\mathbf{E C ~}(\boldsymbol{\mu S} / \mathbf{c m})$ & $\mathbf{T D S}(\mathbf{m g} / \mathbf{L})$ & $\mathbf{N O}_{\mathbf{3}}(\mathbf{m g} / \mathbf{L})$ & $\left.\mathbf{P O}_{\mathbf{4}} \mathbf{( m g} / \mathbf{L}\right)$ \\
\hline W Sample 1 & 3 & $6.23 \pm 0.14$ & $1.33 \pm 0.15$ & $237.33 \pm 3.79$ & $36.33 \pm 0.58$ & $1.63 \pm 0.15$ & $2.07 \pm 0.06$ \\
\hline W Sample 2 & 3 & $6.18 \pm 0.23$ & $1.07 \pm 0.06$ & $142.67 \pm 2.31$ & $52.33 \pm 2.31$ & $2.13 \pm 0.12$ & $0.13 \pm 0.06$ \\
\hline W Sample 3 & 3 & $7.05 \pm 0.03$ & $0.47 \pm 0.06$ & $132.67 \pm 3.06$ & $41.33 \pm 2.89$ & $0.60 \pm 0.17$ & $1.07 \pm 0.08$ \\
\hline \multicolumn{7}{|c|}{ Rainy Season } \\
\hline W Sample 1 & 3 & $6.72 \pm 0.19$ & $1.63 \pm 0.15$ & $253.33 \pm 5.86$ & $31.67 \pm 0.58$ & $1.17 \pm 0.06$ & $3.03 \pm 0.12$ \\
\hline W Sample 2 & 3 & $6.91 \pm 0.02$ & $1.13 \pm 0.02$ & $156.67 \pm 0.58$ & $43.33 \pm 2.89$ & $2.27 \pm 0.12$ & $0.13 \pm 0.06$ \\
\hline W Sample 3 & 3 & $6.34 \pm 0.29$ & $0.67 \pm 0.21$ & $142.33 \pm 0.58$ & $42.67 \pm 1.15$ & $0.67 \pm 0.06$ & $1.23 \pm 0.23$ \\
\hline WHO Std. & & $6.00-9.00$ & 1.00 & 350.00 & 500.00 & 50.00 & 0.30 \\
\hline
\end{tabular}
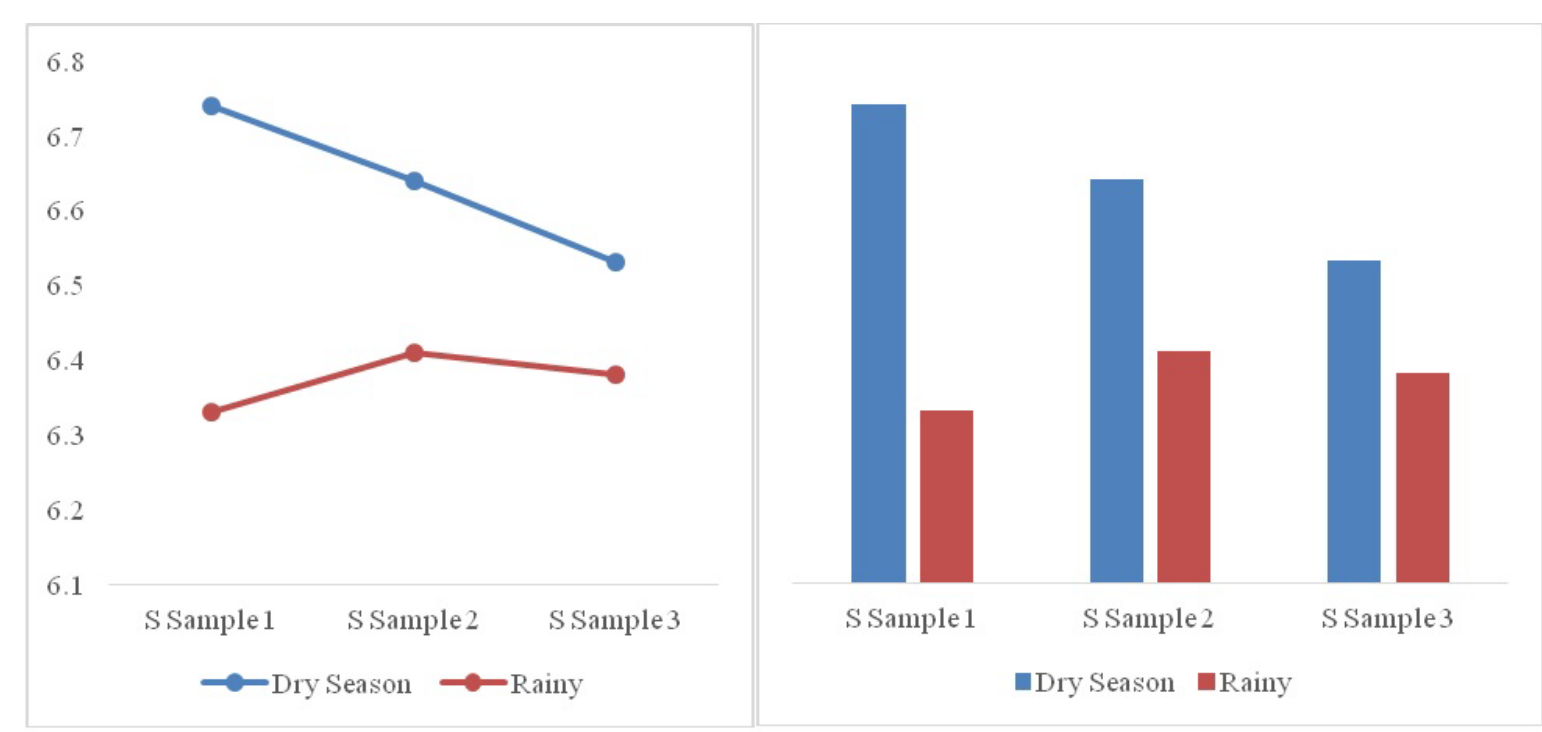

Figure 2: Result of $\mathrm{pH}$ showing a decreasing trend from dry season to rainy season in the soil samples.

a maximum of $1 \mathrm{NTU}$ as the threshold values of turbidity in drinking water; however, the results in this study showed that all but one of the samples recorded turbidity values above the threshold. Nevertheless, the mean turbidity values (Table 2 and Table 3 ) in this study were lower than the values reported by other authors in literature [21]. Generally, the turbidity values of the waters were higher during the rainy season compared to the dry season and a decrease in values was observed as the sampling points moved away from the dumpsite. This suggest that the hand dug wells in proximity to the dumpsite may experience high influx of organic matters, chemical particles and other microorganisms emanating from the dumpsite, especially during the rainy season.

EC, which measures the ability for aqueous solution to conduct current, depends on the amount of dissolved ionic contaminants in the water, and therefore, gives an indication of the extent of chemical pollution in water. The result obtained for EC in this study showed that the samples closer to the dumpsite were more mineralized than sample further away from the dumpsite. The conductivity levels of the groundwater closer to the dumpsite were generally higher than those further away from the dumpsite. All the recorded 
EC values were within the $350 \mu \mathrm{S} / \mathrm{cm}$ limit set by the WHO for drinking water and were higher than those reported in study conducted in Egypt [22].

TDS values recorded in this study were lower than $60 \mathrm{mg} / \mathrm{L}$, which is significantly lower than the $500 \mathrm{mg} / \mathrm{L}$ limit established by WHO. The low values confirm the low EC values obtained for the samples and may suggest less infiltration of solids particles emanating from the dumpsite into groundwater sources in the study area. According to Oluyemi, et al. [23], the flow of rain and surface water reduces the infiltrations of solids particles and thus reduces TDS levels in groundwater aquifers. The results were also lower than the result found in similar study conducted in Nigeria [24].

The values obtained for nitrate in the study showed a decrease in values from water to soil and also from rainy season to dry season. Nitrate mean values were in agreement with values reported by other authors in literature [23]. The WHO has established a value of $50 \mathrm{mg} / \mathrm{L}$ as the permissible limit for nitrate in drinking water. All the water samples analyzed recorded values below $10 \mathrm{mg} / \mathrm{L}$, which is below the value recommended by the WHO guidelines. Nitrate can occur naturally in groundwater as a result of soil leaching and is generally found following an anthropogenic contamination. Municipal and industrial wastes containing leachates from waste disposal sites enhance high concentrations of nitrate [25].

For phosphate, only one of the groundwater samples analyzed recorded low value. All the other groundwater samples analyzed recorded values above the limit $(0.30$ $\mathrm{mg} / \mathrm{L}$ ) recommended by the WHO water quality guideline for drinking water, suggesting possible adverse health effects of phosphate to consumers of the waters in the study area. Generally, there was an increase in phosphate concentration soil to water. The lower mean values of phosphate recorded in the soil samples suggest that phosphate levels in the groundwater samples along the study locality do not originate from the dumpsite but may be due to background levels associated with the natural environment [26]. Phosphates are soluble in water. They are released during rock weathering and their distribution rate is enhanced by erosion [27].

The concentration of heavy metals in soil and water samples are summarized in Figure 3 and Figure 4 respectively. The result showed similarities in the mean concentrations of copper in both soil and groundwater samples. This suggest that the impact of copper on the water resources could be cumulative and not necessarily from the dumpsite. Copper values recorded for the water samples were within the $2 \mathrm{mg} / \mathrm{L}$ guideline value recommended for drinking water by the WHO and were in confirmative with results reported by Ugwoha and Emete [28] in a study conducted in Nigeria. Copper is an essential element but adverse health effects are related to both deficiency and excesses. Deficiency of copper in the diet can cause symptoms such as anaemia, neutropenia and bone abnormalities and Menkes disease. Conversely, an excess of copper may lead to the development of Wilson disease [29].

There was a general increase in zinc, cadmium and lead concentrations from the dry season to the rainy season, with mean levels higher in soil samples than water samples, suggesting that the contamination of groundwater within the vicinity of New Georgia by the metals may originate from the dumpsite and get into groundwater sources through seepage or erosion. Cadmium, like zinc and lead in soil, can be reduced by organic matters and weathering and subsequently enters groundwater through percolation. All the values recorded for the metals were within their respective guideline values recommended by the World Health Organization. The noticeable exceptions were lead and cadmium, which recorded values equal to or higher than the recommended limit of $0.01 \mathrm{mg} / \mathrm{L}$ and $0.003 \mathrm{mg} / \mathrm{L}$ respectively established

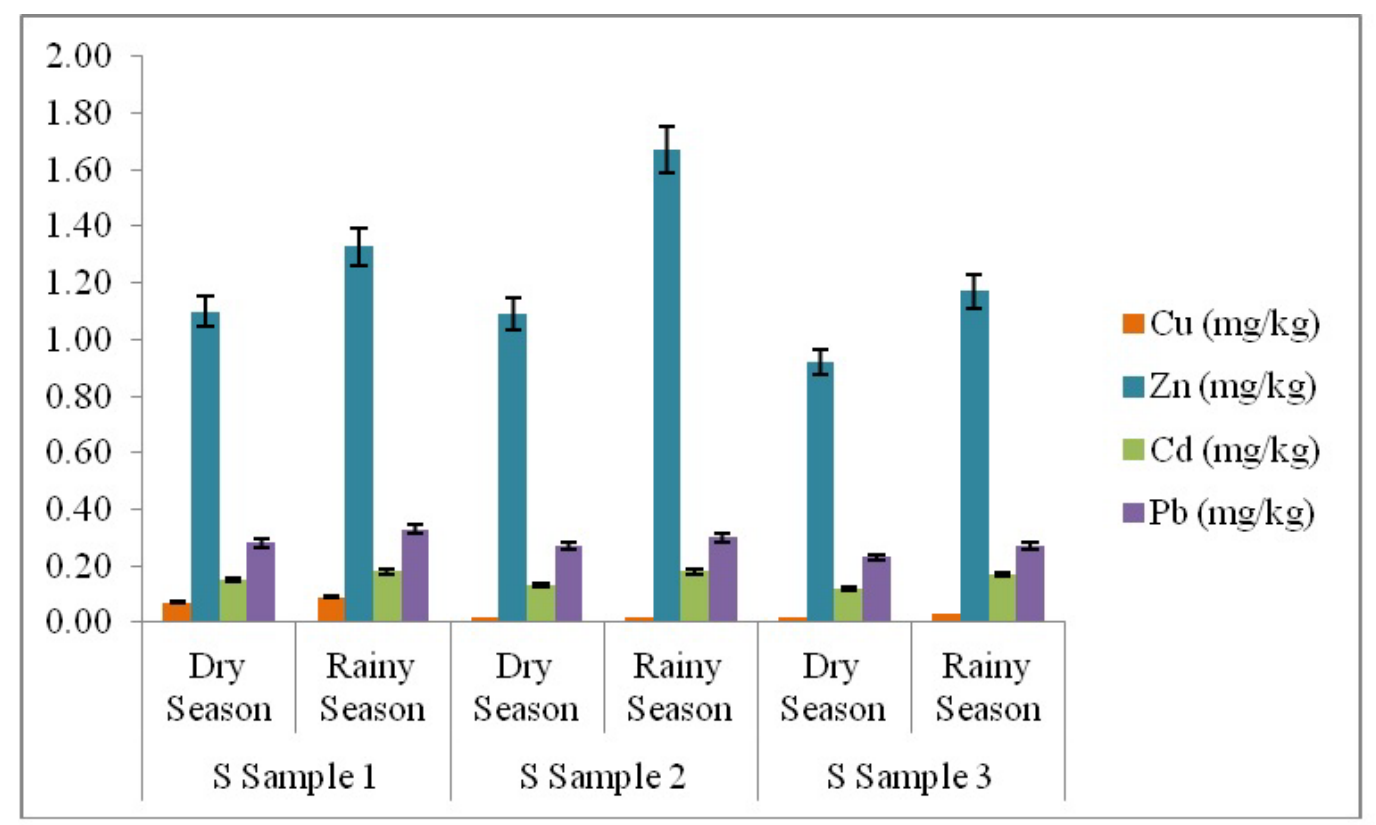

Figure 3: Results of Metals in the Soil Samples for each sampling period. 


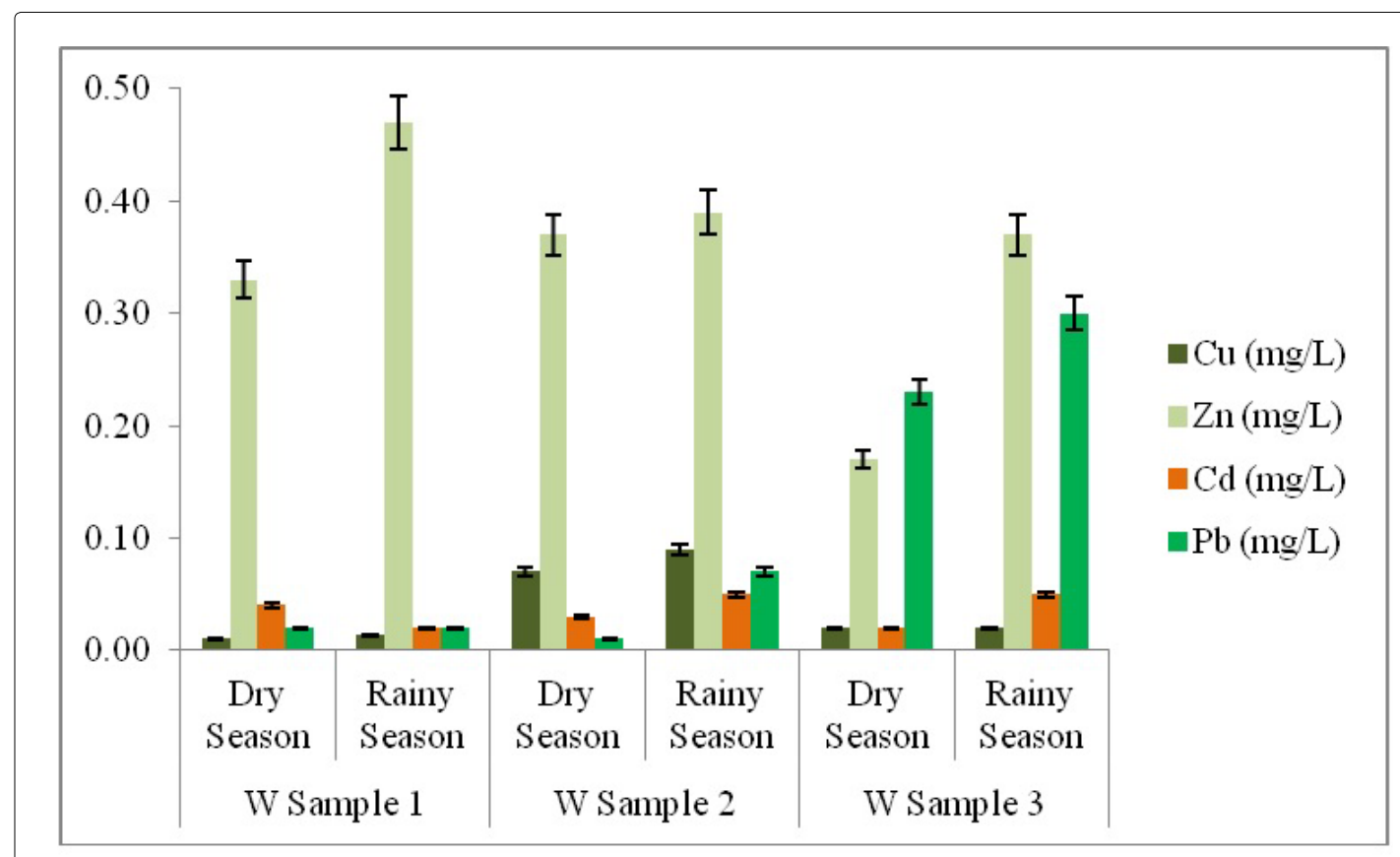

Figure 4: Results of Metals in the Water Samples for each sampling period.

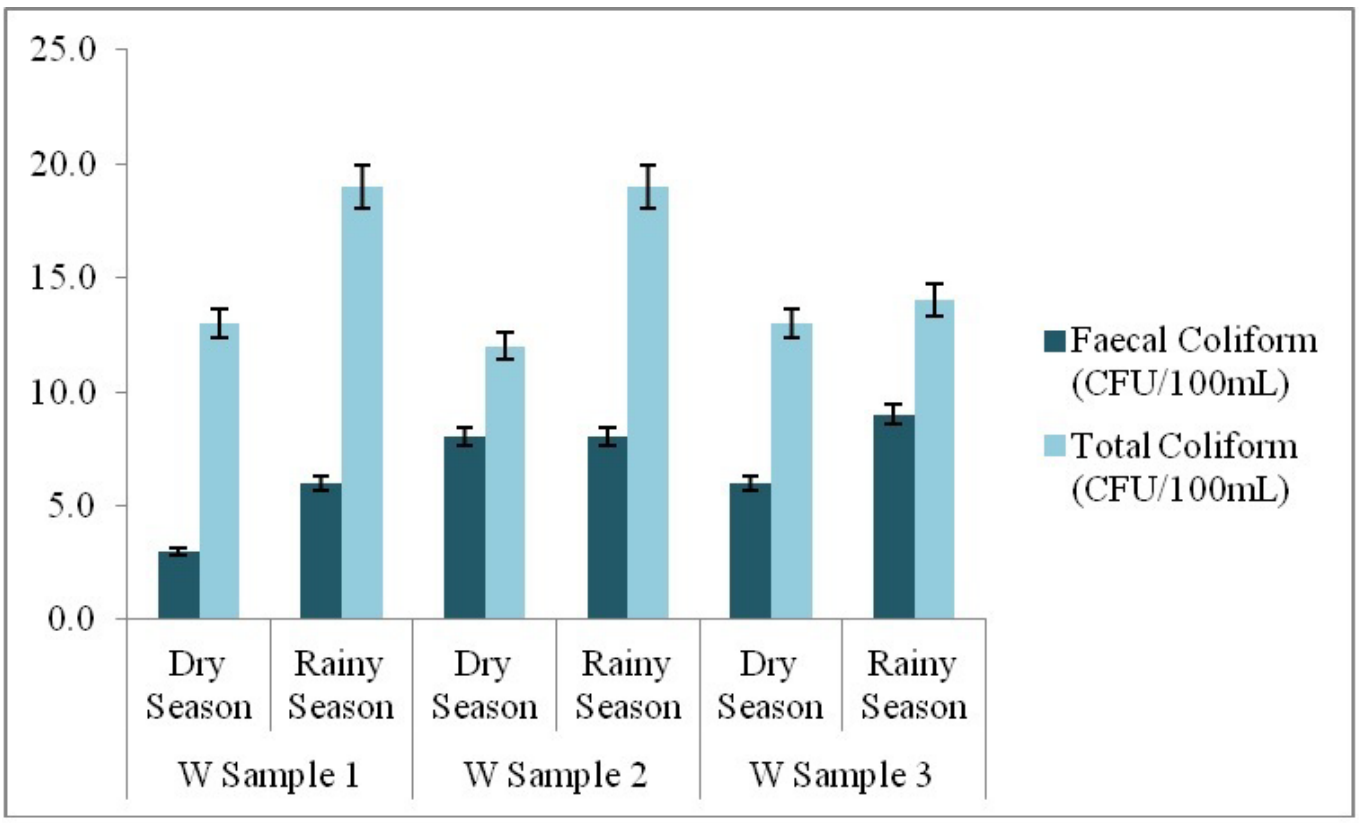

Figure 5: Results of Coliforms in the water samples for each sampling period.

by the World Health Organization for drinking water. Lead toxicity affects the nervous system and has damaging effects on the brain and kidneys. Infants and children who drink water containing lead in excess of the threshold level could experience delays in their physical or mental development. They could have deficits in attention span and learning abilities while adults who take such waters could easily develop kidney problems or high blood pressure. Values reported for heavy metals were below the study piloted in India by Kanmani and Gandhimathi [30].

In addition to physicochemical parameters, the study also considered faecal coliforms and total coliforms in the water samples. Both coliforms were present in the water resources across both seasons (Figure 5), thus did not meet the $0.0 \mathrm{CFU} / 100 \mathrm{~mL}$ permissive limits recommended for both faecal and total coliforms by WHO. The presence of coliform bacteria in the water samples indicates contamination arising from fecal material of man or other animals, as well as pathogens or disease-producing bacteria or viruses, at the time of the study. However, the alarming sequence of the result showed a cumulative impact, and not necessarily the dumpsite. It also showed a possible adverse health effect resulting from coliforms to the consumers of the water resources. 
Citation: Fallah CF, Gomah LG, Ngumbu RS, et al. (2021) Evaluation of Soil and Groundwater Quality at the New Georgia Open Dumpsite in Caldwell, Liberia. J Soil Water Sci 5(2):197-204

Table 4: WQI for the water sampled in this study.

\begin{tabular}{|c|c|c|c|c|c|c|}
\hline Parameter & Mean & Std & Q & W & WQI & \% Contributed \\
\hline Turb & 1.05 & 1.00 & 105.00 & 1.00 & 105.00 & 0.56 \\
\hline $\mathrm{EC}$ & 177.50 & 350.00 & 50.71 & 0.00 & 0.14 & 0.00 \\
\hline $\mathrm{TDS}$ & 41.28 & 500.00 & 8.26 & 0.00 & 0.02 & 0.00 \\
\hline $\mathrm{NO}_{3}$ & 1.41 & 50.00 & 2.82 & 0.02 & 0.06 & 0.04 \\
\hline $\mathrm{PO}_{4}$ & 1.02 & 0.30 & 338.89 & 3.33 & 1129.63 & 6.07 \\
\hline $\mathrm{Cu}$ & 0.04 & 2.00 & 1.83 & 0.50 & 0.92 & 0.00 \\
\hline $\mathrm{Zn}$ & 0.35 & 0.50 & 70.00 & 2.00 & 140.00 & 0.75 \\
\hline $\mathrm{pH}$ & 6.57 & 7.50 & 87.60 & 0.13 & 11.68 & 0.06 \\
\hline $\mathrm{Cd}$ & 0.04 & 0.03 & 116.67 & 33.33 & 3888.89 & 20.90 \\
\hline $\mathrm{Pb}$ & 0.01 & 0.01 & 133.33 & 100.00 & 13333.33 & 71.65 \\
\hline
\end{tabular}

To further assess the pollution or suitability of the groundwater sources for drinking, a water quality index valuation was conducted. Results from the assessment showed a varying quality classification ranging from excellent to unsuitable based on different parameters (Table 4). However, cumulative quality index value (132.62) showed that the sampled groundwater sources in the study area are unsuitable for drinking, further confirming a possible adverse health effect of those contaminants to the consumers of the groundwater. In addition to the microbiological parameters, the unsuitability of the water sources for consumption is due also to the high level of lead, cadmium and phosphate in the water samples. Lead, cadmium and phosphate contributed $71.6 \%, 20.9 \%$ and $6 \%$ to the cumulative WQI value respectively.

\section{Conclusion}

The study analyzed soil and groundwater samples collected at varying distances to the New Georgia functional open dumpsite in order to assess the impact of the dumpsite on the qualities of the environmental matrices. Results showed that the groundwater has values of many parameters within limit of WHO. However, the values for microbial parameters, as well as turbidity, phosphate, cadmium and lead exceeded the regulatory limit or were just on the benchmark. With the exception of phosphate and copper, all the other parameters showed decrease in values from soil to water and from rainy season to dry season. A decrease in values was also observed as the samples moved further way from the dumpsite, indicating an appreciable infiltration and migration of leachate emanating from the dumpsite through soil and to water acquirers. Ultimately, the dumpsite is adversely impacting the qualities of soil and groundwater within the locale of New Georgia. Cumulative water quality index value showed that the sampled groundwater sources in the study area are unsuitable for drinking. Hence, residence should also be cautioned about drinking water from all of the tested sources, and measures should be put in place to provide alternative water supplies. Furthermore, the garbage at the dumpsite should be removed and the site properly remediated to avoid impending environmental health adversities.

\section{Acknowledgement}

The authors are grateful to the management of the Environment Protection Agency (EPA) Liberia for granting the authors the opportunity to use the Agency's Laboratory to carry out parts of this research. The authors also extend gratitude to the Chairman and staff of the Chemistry Department, University of Liberia for granting the opportunity to use their laboratory for some of the experiments.

\section{Conflict of Interest}

The authors declared no conflict of interest with respect to the publication of this article.

\section{References}

1. Aladejana JA, Odeyemi OO, Tijani MN, et al. (2018) Integrated assessment of leachate concentration in soil underlying amuloko open waste dumpsite, Ibadan SouthWestern, Nigeria. J Min Geol 54: 1-11.

2. Ali SM, Pervaiz A, Afzal B, et al. (2013) Open dumping of municipal solid waste and its hazardous impacts on soil and vegetation diversity at waste dumping sites of Islamabad city. J King Saud University-Science 26: 59-65.

3. Venâncio MD, Pope K (2018) Solid waste management and the practice of open dumping in Brazil: Lessons learnt from the state of santa Catarina. Journal of Vasyl Stefanyk Precarpathian National University 5: 178-189.

4. Bhada-Tata P, Hoornweg D (2012) What a waste: A global review of solid waste management. World Bank.

5. Amadi AN, Ameh ML, Jisa J (2010) The impact of dumpsites on groundwater quality in markurdi metropolis, Benin State. Nat Appl Sci J 11: 90-102.

6. Parthiban L, Mahindrakar AB (2016) Contamination transport in groundwater from municipal solid waste landfill pollutants. Int J Adv Res 4: 4-9.

7. Kundiri AM, Umdagas BA, Oumarou MB (2017) Characterization of leachate contaminants from waste dumpsites in Maiduguri, Borno State. Arid Zone Journal of Engineering, Technology and Environment 13: 140-148.

8. Goswanmi U, Sarma HP (2007) Study of groundwater contamination due to municipal solid waste dumping in Guwahati city. Pollution Research 26: 211-214.

9. Sia Su GL (2008) Assessing the effects of a dumpsite to groundwater quality in Payatas, Philippines. American J Environ Sci 4: 276-280.

10. Andrew AA, Jun $S$, Takahiro $H$, et al. (2011) Evaluation of groundwater quality and its suitability for drinking domestic and agricultural uses in the Banana Plain (Mbanga, Njombe, Penja) of the Cameroon volcanic line. Environ Geochem Health 33: 559-575. 
11. Majolagbe AO, Kasali AA, Ghaniyu LO (2011) Quality assessment of groundwater in the vicinity of dumpsite in Ifo and Lagos, Southwestern Nigeria. Adv Appl Sci Res 2: 289-298.

12. UNEP (2007) Integrated Solid Waste Management. United Nations Environmental Programme.

13. Abdulrafiu OM, Adebola AA, Oladele O, et al. (2017) Pollution vulnerability and health risk assessment of groundwater around an engineering Landfill in Lagos, Nigeria. Chem Int 3: 58-68.

14. Hadden LR (2006) The geology of Liberia: A selected bibliography of liberian geology, geography and earth science. Topographic Engineering Center. Alexandria.

15. Baysah YC, Ngumbu RS, Fayia AK, et al. (2018) Geotechnical characterization of soils for use as landfill liner: A case study of soil samples from the paynesville sandstone and farmington river formation, Liberia. Int J S Res Sci Technol 4: 70-75.

16. Kachroud M, Trolard F, Kefi M, et al. (2019) Water quality indices: Challenges and application limits in the literature. Water 11: 361-381.

17. Ishaku JM (2011) Assessment of groundwater quality index for Jimeta-Yola area, northeastern Nigeria. J Geol Min Res 3: 219-231.

18. Galarpe VRK, Parilla RB (2012) Influence of seasonal variation on the biophysicochemical properties of leachate and groundwater in cebu city sanitary dumpsite, Philippines. International Journal of Chemical and Environmental Engineering 3: 175 -181.

19. Chaudhari GK (2013) Studies of the physiochemical parameters of soil samples. Adv Appl Sci Res 4: 246-248.

20. WHO (2017) Guidelines for drinking-water quality: Fourth edition incorporating the first addendum. World Health Organization.

21. Al-Ani IA (2019) Mathematical computation of water quality index for the assessment of al-hilla river ecosystem. International Journal of Civil Engineering and Technology 10: 1862-1869.
22. El-Salem MM, Abu-Zuid GI (2015) Impact of landfill leachate on the groundwater quality: A case study in Egypt. J Adv Res 6: 579586.

23. Oluyemi EA, Adekunle AS, Adenuga AA, et al. (2010) Physicochemical properties and heavy metal content of water sources in ife north local government area of Osun State, Nigeria. Afr J Environ Sci Technol 4: 691-697.

24. Aboyeji OS, Eigbokhan E (2016) Evaluations of groundwater contamination by leachates around Olusosun open dumpsite in Lagos metropolis, southwest Nigeria. J Environ Manage 183: 333-341.

25. Davies B, Valente MB, Hall A (2005) The Zambezi Rivers in Mozambique: The physicochemical status of the middle and lower Zambezi prior to the closure of the Cobora Bassa Dam. Freshwater Biology 7: 187-189.

26. Gunn AG, Dorbor JK, Mankelow JM, et al. (2018) A review of the mineral potential of Liberia. Ore Geology Reviews 101: 413-431.

27. Longe EO, Enekwechi LO (2007) Investigation on potential groundwater impacts and influence of local hydrogeology on natural attenuation of leachate at a municipal landfill. Int J Environ Sci Tech 4: 133-140.

28. Ugwoha E, Emete KC (2015) Effects of open dumpsite leachate on groundwater quality: A case study of alakahia dumpsite in port harcourt, Nigeria. J Environl Stud 1: 8.

29. Gomah LG, Ngumbu RS, Voegborlo RB (2019) Dietary exposure to heavy metal contaminated rice and health risk to the population of monrovia. J Environ Sci Public Health 3: 474-482.

30. Kanmani S, Gandhimathi R (2013) Investigation of physicochemical characteristics and heavy metal distribution profile in groundwater system around the open dumpsite. Appl Water Sci 3: 387-399.

DOI: $10.36959 / 624 / 445$

Copyright: (c) 2021 Kikuchi K. This is an open-access article distributed under the terms of the Creative Commons Attribution License, which permits unrestricted use, distribution, and reproduction in any medium, provided the original author and source are credited. 